\title{
Caddo Ceramics on the Red River in North Central Texas
}

Timothy K. Perttula

Heritage Research Center, Stephen F. Austin State University

Earnest R. Martin

Bo Nelson

Heritage Research Center, Stephen F. Austin State University

Follow this and additional works at: https://scholarworks.sfasu.edu/ita

Part of the American Material Culture Commons, Archaeological Anthropology Commons, Environmental Studies Commons, Other American Studies Commons, Other Arts and Humanities Commons, Other History of Art, Architecture, and Archaeology Commons, and the United States History Commons

Tell us how this article helped you.

This Article is brought to you for free and open access by the Center for Regional Heritage Research at SFA ScholarWorks. It has been accepted for inclusion in Index of Texas Archaeology: Open Access Gray Literature from the Lone Star State by an authorized editor of SFA ScholarWorks. For more information, please contact cdsscholarworks@sfasu.edu. 


\section{Caddo Ceramics on the Red River in North Central Texas}

Creative Commons License

(c) (i) (8)

This work is licensed under a Creative Commons Attribution-NonCommercial 4.0 International License 


\section{Caddo Ceramics on the Red River in North Central Texas Timothy K. Perttula, Ernest R. Martin, and Bo Nelson}

Caddo ceramics manufactured after A.D. 900 were widely traded in Texas, being found in some quantity on North Central, East Central, Central, and inland Southeast Texas archeological sites (Story 1990:247). They were also traded with prehistoric peoples in the Midwest (as far north as Iowa and Illinois) and the Southeastern U.S. While archeologists have known this for some time, much of the ceramic evidence for prehistoric Caddoan trade and exchange with other Native Americans has not been systematically compiled and studied, as became apparent during a recent review of the prehistoric and historic aboriginal pottery in Texas (Perttula et al. 1995). Consequently, Caddoan archeologists are not yet in the position to confidently discuss the scope, timing, or direction of trade/exchange between Caddoan groups and surrounding non-Caddoan communities, or explore changes in the nature of social and economic relationships between particular Caddo groups and other prehistoric peoples.

This paper represents part of our initial efforts to begin systematically compiling archeological information on the distribution and character of Caddo ceramic sherds and vessels outside what is considered the southern Caddoan archaeological area (Perttula 1996:Figure 1). In it, we report on Early and Late Caddo ceramies found by Dr. Ernest R. Martin at two sites along the Red River in North Central Texas, some $130 \mathrm{~km}$ or more west of the westernmost Caddo settlements on the Red River in Northeast Texas.

Although the sites are in the Red River valley, in the larger sense, both sites that we describe here are in the Eastern Cross Timbers. This. is a narrow band of sandy, rolling and dissected hills covered with oaks but interspersed with pockets of tall-grass prairie (Prikryl 1990). Late Prehistoric sites (ca. A.D. 700-1700) in this area are common in the Red River valley, along the headwaters of the Trinity River, and along Cross Timbers-prairie boundaries (see Prikryl 1990:79, 82). 
Portions of a Crockett Curvilinear Incised bowl were found on the north side of Lakc Texoma and Willis Bridge where U.S. Highway 377 enters the state of Oklahoma. The site is just upstream of the conflucnce of Big Mincral Creek and the Red Rivcr. The bowl, found first in 1987 by Terry Zunk, was scattered down the steep lake bank about 30 meters east of the bridge. They had probably been washed or eroded out from higher up the terracc, and some of the sherds were found among the large boulders around the edge of the bridge during construction. Martin and Zunk returned to the site threc times, finding additional sherds each time. None of the sherds werc cver found in situ, and the only other archeological finds were a few lithic flakes.

The Crockett Curvilinear Incised globular bowl (Suhm and Jelks 1962:Plate 16d, f) is comprised of 18 sherds that join to make eight larger sherds; the largest sherd segment is $13.5 \mathrm{~cm}$ wide and $8.4 \mathrm{~cm}$ in length (Figure 1a). The bowl was tempered with grog and pulverized/burned bone; an occasional hematite chunk (some ranging up to $3 \mathrm{~mm}$ in size) was also employed as an aplastic. The paste texture is coarse and lumpy, with large temper particles.

Its color is light reddish brown with dark brown fire clouds on both exterior and interior surfaces. Paste color ranges from completely oxidized to completely reduced, suggesting poor control of the firing environment. The surface finish is smoothed on the exterior, and patches of burnishing are evident. The interior, however, is unsmoothed, with clay lumps (from incompletely smoothed coils) protruding from the surface, and it is pocked from temper erosion.

The sherd body wall thickness ranges from $8.5-9 \mathrm{~mm}$ near the base of the body wall, and 6-6.5 $\mathrm{mm}$ near the top of the body wall. This is consistent with the body thickness range described by Suhm and Jelks (1962:31).

The decoration on the vessel consists of 44-46 $\mathrm{mm}$ diameter incised circles filled either with hemiconical or small round punctates, with small diameter $(15 \mathrm{~mm})$ incised but plain circles within the larger circle (Figure 1a-b). Extending from the incised/punctated 

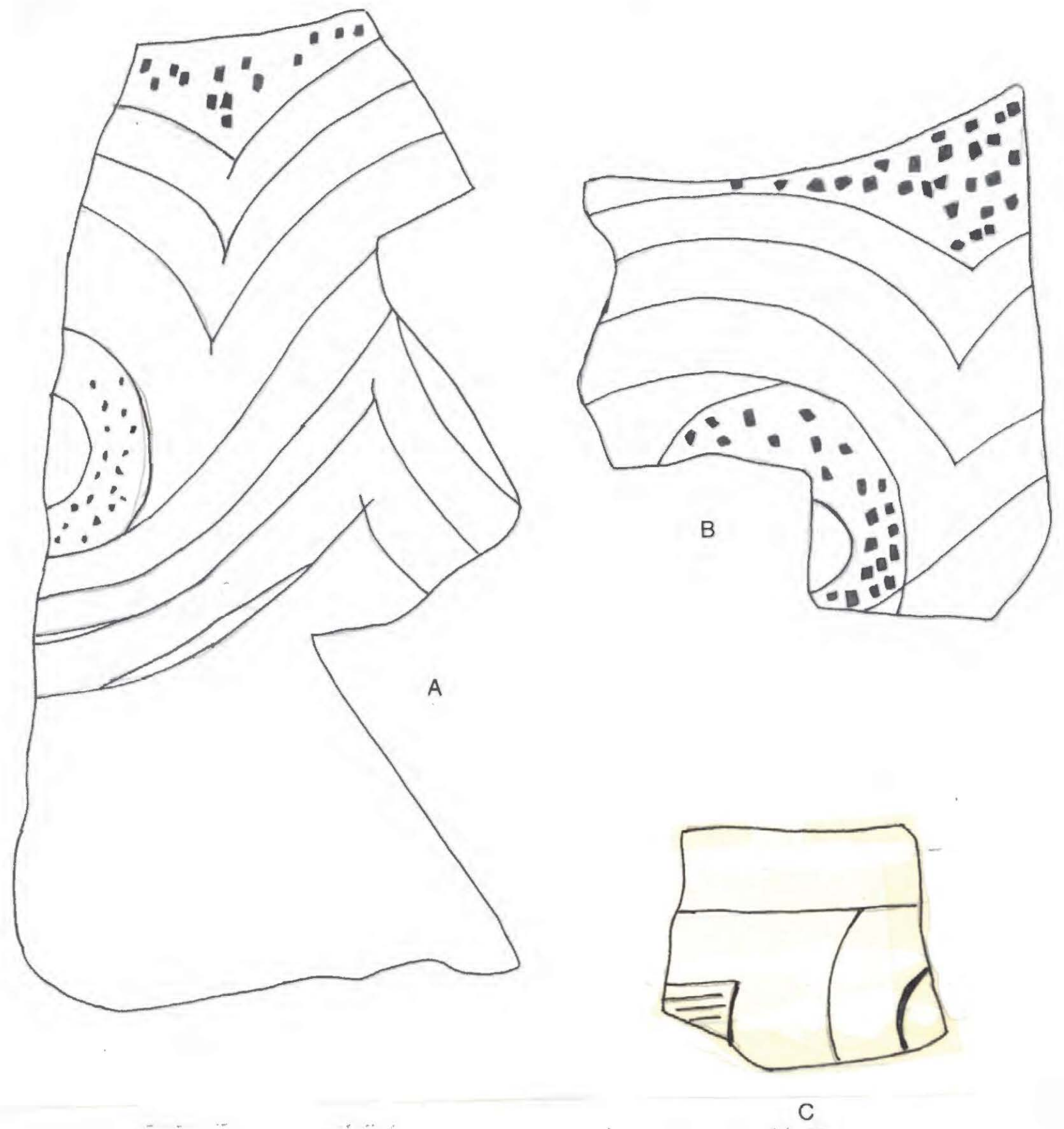

Figure 1. Caddo Ceramics from the Lake Texoma area: a-b, Crockett Curvilinear Incised bowl sections, Willis Bridge; c, Crockett Curvilinear Incised sherd, Willis Bridge. 
circles are threc curvilinear and deeply incised lines (done when the vessel was leatherhard) that are $8-9 \mathrm{~mm}$ apart, that run towards punctated fillers (also hemiconical) near the top of the design. The lower portion of the decorative element is defined by the merging sets of incised lines (see Figure 1a). On some parts of the vessel, the incised lines are not well-executed, and they suggest that the initial incising effort was abortive because they are short, narrow segments immediately adjacent to the finished, completed incised design element (see Figure 1a).

There is a single miscellaneous Crockett Curvilinear Incised sherd in the Willis Bridge collection. It possibly is associated with other vessel described above, although the paste and decorative elements are somewhat different. It has a finely-ground grog, grit, and bone temper, with finely incised curvilinear lines extending from a single horizontal incised line, and narrowly spaced incised lines employed as the filler (Figure 1c). Although the Crockett Curvilinear Incised vessel section mentioned above has punctation fillers, Suhm and Jelks (1962:31) do note the alternating use of punctated and incised fillers on the same vessel. The sherd's wall thickness is $8 \mathrm{~mm}$. In color, this Crockett sherd ranges from reddish-brown to gray (with fire-clouding), and it is unsmoothed and unburnished.

Late Caddo ceramics were found by Martin 200 meters west-northwest of Brown Springs (Love County, Oklahoma) in a Sand pit operation in 1967, about 800 meters south of Interstate 35 where it crosses into Oklahoma. This is just upstream of the extreme headwaters of Lake Texoma, about $13 \mathrm{~km}$ north of Gainesville, Texas. The confluence of Fish Creek and the Red River, an area where Late Prehistoric Plains Village sites are common (Lorrain 1969; Martin 1994), is about 4-5 km upstream of Brown Springs.

Sherds from a portion of a red-slipped V-shaped Avery Engraved jar were found broken in a pile of sand mined from the pit, and Martin pieced the sherds together. Other artifacts he found nearby included Washita, Bonham, and Fresno arrowpoints, a fragmented human skeleton (based on a photograph taken by Martin, the individual was an adult lying flexed on its side with the head facing left and the hands out in front of the 
face), Nocona Plain shell-tempered sherds, galena, a bison foreleg (including hoof), bone awl, grinding stones, abraders (shaft and flat), and pieces of ochre. Clearly the site had a Late Prehistoric Plains Village period (ca. A.D. 1250/1300-1600) occupation (see Brooks 1994; Martin 1994). The site was subsequently destroyed around 1972 by sand mining to depths of 25-30 feet.

The partial vessel or large sherd $(15.3 \times 11.1 \mathrm{~cm}$ in length and width) is composed of 53 conjoined sherds that comprise one side of a well-made vessel from the base/body juncture to near the rim. The sherds are tempered with finely pulverized and burned shell, and the paste texture is fine and compact, but with some leaching of shell aplastics. The vessel was red-slipped, on both exterior and interior surfaces, and has a gray core. It also has a polished but eroded surface finish; the red-slip is eroded in a few areas. Wall thickness of the vessel section ranges from 5-6 mm, and the body wall becomes slightly thicker towards the base. The base is slightly concave, with little difference in body wall and base thickness; the red slip has been slightly worn off on the outside on this portion of the vessel.

The sherds are likely to be from a large Avery Engraved jar with a vertical rim (cf. Suhm and Jelks 1962:Plate 2a, f, i). It has a deep, plain body, and would have had engraved bands along the rim. The height of the undecorated jar body wall $(+15 \mathrm{~cm})$ suggests that this jar is probably the post-A.D. 1450 variety of Avery Engraved (see Perino 1994:29 and Figure 12), as these had engraved bands that extended from the upper rim only about one-third of the way down the vessel wall; this large sherd/vessel section occurs just below the engraved rim band.

\section{Concluding Comments}

The recovery of sherds from Caddo vessels in the Lake Texoma area documents two different periods of apparent trade and exchange between local Plains Village groups and Caddo groups living in Northeast Texas andor Southeast Oklahomala. The Crockell 
Curvilinear Incised vessel denotes trade sometime prior to A.D. 1300, since Crockett Curvilinear Incised vessels were widely manufactured in many parts of Northeast Texas between ca. A.D. 900-1300. Further petrographic and chemical characterization studies would be necessary to determine the source of this vessel within Northeast Texas, but given the frequency of Crockett Curvilinear Incised at Red River Caddo sites such as Holdeman (Perino 1995) and Bentsen-Clark (Banks and Winters 1975), we suspect that the Lake Texoma vessel derives from the Red River Caddo settlements in Northeast Texas.

The Avery Engraved bowl sherds from the upper Lake Texoma area, on the other hand, documents Plains Village-Late Caddo trade and exchange after ca. A.D. 1450. Avery Engraved is a common Caddo decorated ceramic in McCurtain phase contexts along the Middle Red River in Northeast Texas and Southeast Oklahoma (see Perino 1994, 1995), and this is surely the source of the sherds found by Ernest Martin some 20+ years ago.

\section{References Cited}

Banks, L. D. and J. Winters

1975 The Bentsen-Clark Site, Red River County, Texas: A Preliminary Report. Special Publication No. 2. Texas Archeological Society, San Antonio.

Brooks, R. E.

1994 Southern Plains Cultural Complexes. In Skeletal Biology in the Great Plains: Migration, Warfare, Health, and Subsistence, edited by D. W. Owsley and R. L. Jantz, pp. 33-50. Smithsonian Institution Press, Washington, D.C.

Lorrain, D.

1969 Archaeological Excavations in the Fish Creek Reservoir. Contributions in Anthropology Number 4. Department of Anthropology, Southern Methodist University, Dallas.

Martin, E. R.

1994 The Dillard Site: A Late Prehistoric Plains Village Site in Cooke County, Texas. Bulletin of the Texas Archeological Society 62:105-200.

Perino, G.

1994 Archaeological Research at the Rowland Clark Site (41RR77), Red River County, Texas. Journal of Northeast Texas Archaeology No. 4:3-42.

1995 The Dan Holdeman Site (4IRR11), Red River County, Texas. Journal of Northeast Texas Archaeology No. 6:3-65. 
Perttula, T. K.

1996 Caddoan Area Archaeology Since 1990. Journal of Archaeological Research 4 (No. 4):295-348.

Perttula, T. K., M. R. Miller, R. A. Ricklis, D. J. Prikryl, and C. Lintz

1995 Prehistoric and Historic Aboriginal Ceramics in Texas. Bulletin of the Texas Archeological Society 66:175-235.

Prikryl, D. J.

1990 Lower Elm Fork Prehistory: A Redefinition of Cultural Concepts and Chronologies along the Trinity River, North-Central Texas. Report 37. Office of the State Archeologist, Texas Historical Commission, Austin.

Story, D. A.

1990 Cultural History of the Native Americans. In The Archeology and Bioarcheology of the Gulf Coastal Plain, by D. A. Story, J. A. Guy, B. A. Burnett, M. D. Freeman, J. C. Rose, D. G. Stcele, B. W. Olive, and K. J. Reinhard, pp. 163-366. 2 Vols. Research Series No. 38. Arkansas Archeological Survey, Fayetteville.

Suhm, D. A. and E. B. Jelks

1962 Handbook of Texas Archeology: Type Descriptions. Texas Archeological Society, Special Publication No. 1, and Texas Memorial Museum, Bulletin No. 4. Austin. 